\title{
Coffee in the diet and prevention of diabetes
}

\section{ABSTRACT}

The impact of coffee consumption on health deserves an attention, especially in the context of patients' ongoing concerns about its adverse health effects. Knowledge on this subject may also inform the clinical practice. Objective - to present the current state of knowledge about the relationship between coffee consumption and the incidence of diabetes type 2 . Epidemiological studies indicate that the habit of coffee consumption reduces the risk of non-insulin-dependent diabetes. Drinking at least 3 cups of coffee a day reduces the risk of this disease by $20-25 \%$, and higher consumption may portend even more protection. The beneficial effect of coffee is most likely due to polyphenols present in the infusion, which have an anti-inflammatory effect and may improve insulin sensitivity. The content of bioactive ingredients in a cup of coffee is variable, depending on both the natural variation in coffee beans and the brewing method. The issue of sweetening coffee is a particularly important one as the addition of sugar can reduce its beneficial effects. Moderate consumption of coffee brewed using filters (3-5 cups per day) is recommended.

Current scientific research indicates that coffee not only has no negative impact on health but may even reduce the incidence of diabetes. (Clin Diabetol 2020; 9; 2: 144-148)

Key words: coffee, diabetes, health

\section{Introduction}

Diabetes type 2 is one of the most common metabolic diseases, associated with excess body weight, sedentary lifestyle, and inappropriate diet. Nutrition scientists are thus looking for dietary approaches to reduce its incidence. In addition to recommendations to reduce sugar intake and increase intake of vegetables and whole grain products, dietary guidelines have included a recommendation to drink coffee [1, 2]. An analysis of the results of recent studies on the health effects of drinking coffee led to including a cup of coffee in the recently updated food pyramid of the Food and Nutrition Institute [3]. Thus, after years of the prevailing belief of negative or at least risky health effects of coffee drinking, currently available studies indicate otherwise. Coffee is no longer considered a substance, which is defined as a product which has no nutritional value for the body, but rather as a component of a healthy diet. According to experts from the United States and the Netherlands, moderate coffee intake fits well within the currently recommended nutrition, and coffee may even be included among so-called functional foods $[2,4-6]$.

\section{Coffee and its constituents}

Similarly to other food products, coffee contains specific compounds. In addition to well-known caffeine, these include polyphenols, diterpenes, niacin, and magnesium.

Caffeine in an alkaloid occurring naturally in some plant sources, mainly coffee, tea, and cocoa beans. Food industry also uses synthetic caffeine, added as an aroma (e.g., in cola-type beverages) or a psychoactive ingredient (e.g., in energy drinks) [7]. Research indicates that the lowest caffeine dose which induces measurable physiological effects in the human body is $75 \mathrm{mg}$. A single dose of $75 \mathrm{mg}$ increases alertness and attention in most adults but its effect may be variable and depends on genetic and environmental factors. It has no effects in some subjects, termed "non-responders 
to caffeine" $[8,9]$. Safe daily intake of caffeine in adults is up to $400 \mathrm{mg}$, and up to $2.5 \mathrm{mg} / \mathrm{kg}$ body mass in children. Excessive caffeine intake may lead to adverse effects including hyperexcitability, muscle tremor, insomnia, headache, and gastric upset [9]. According to the International Statistical Classification of Diseases and Related Health Problems, negative effects of large caffeine intake are categorized as mental and behavioural disorders due to use of other stimulants including caffeine (code F 15.3) [10]. The main action of caffeine in the body is by blocking the receptor for adenosine, a brain neurotransmitter inducing the feeling of fatigue, which leads to increased catecholamine levels (adrenaline, dopamine, serotonin) resulting in the central nervous system stimulation, increase in heart rate, and vasodilatation [11, 12]. This mechanism leads to an overall improvement of mental and physical performance and thus caffeine has an ergogenic effect $[13,14]$. Studies performed in the recent years failed to confirm the previous hypothesis of a beneficial effect of caffeine on fat burning. Thus, nutritional law regulations prohibit suggesting weight-loss properties of caffeine, e.g., on dietary supplements product packages [15].

The caffeine content in coffee is very variable and depends on multiple factors including the botanical species of coffee (Robusta contains twice more caffeine compared to Arabica), cultivation conditions, the degree of bean crushing, brewing method, and the strength of infusion. Due to these factors, it is difficult to predict caffeine content in an individual cup of coffee. Literature data indicate that a cup of coffee may contain 28 to $322 \mathrm{mg}$ of caffeine [16-19]. In one study, the caffeine content in 20 espresso coffees purchased in various cafes varied up to 6-fold [18]. In general, it has been estimated that the average caffeine content in a typical cup of coffee is $80-90 \mathrm{mg}$ [20].

Coffee is also a source of polyphenols. These are a group of plant compounds with complex chemical structure, of which the best known are flavonoids present, e.g., in fruits, tea, and dark chocolate. Polyphenols are food compounds with anti-inflammatory and antioxidant properties. Their large intake is believed to exert an effect comparable to that of non-steroidal antiinflammatory drugs [21]. Similarly to caffeine content, their content in coffee infusion is very variable. It has been estimated that a cup of coffee contains on average about $190 \mathrm{mg}$ of polyphenols [22]. For a comparison, $100 \mathrm{~g}$ of grapes provide $200-300 \mathrm{mg}$ of polyphenols [23]. However, it is difficult to evaluate these amounts in terms of health benefits as the recommended polyphenol intake has not been established. The major polyphenol in coffee is chlorogenic acid which is also considered the most biologically active [24]. Due to its breakdown during prolonged heat processing, the largest amounts of chlorogenic acid are present in green (unroasted) coffee beans [5].

Among other coffee compounds, of major importance are diterpenes (lipid compounds) which may have both positive and negative health effects. While coffee with a high diterpene content increases LDL cholesterol, triglyceride, and homocysteine levels, these compounds also activate liver enzymes which facilitate elimination of toxic metabolism waste products. Diterpenes are most abundant in unfiltered coffee (e.g., Turkish coffee) but nearly absent in filtered and instant coffee $[2,25]$. Coffee infusion also contains niacin and magnesium. According to the Polish national data, a cup of coffee provides $1 \mathrm{mg}$ of niacin and $19 \mathrm{mg}$ of magnesium, or $5-6 \%$ of their recommended daily allowance [26].

\section{Coffee in the prevention of diabetes}

Potential effect of coffee on reducing the risk of non-insulin-dependent diabetes has been discussed in the scientific literature for several years. The interest in this issue surged in 2002 when Dutch researchers published a large epidemiological study that included a population of more than 17000 and showed a lower incidence of diabetes among regular coffee drinkers [27]. The most pronounced effect was noted for the intake of 7 cups per day, with a twice lower incidence of diabetes compared to non-drinkers and those consuming less than 2 cups per day. Consuming 5-6 cups per day was associated with a $27 \%$ reduction in diabetes incidence, and the lowest effect was seen for the consumption of 3-4 cups per day $(21 \%$ reduction in diabetes incidence). In the subsequent years, two independent studies performed in the Netherlands and Japan showed that consuming at least 3 cups of coffee per day was associated with a $42 \%$ reduction in diabetes incidence $[28,29]$. Somewhat lower reduction in risk (by $27 \%$ ) was noted among French women consuming 3 cups of coffee per day [30].

Studies performed in the United States indicate that the effect of coffee consumption on the development of diabetes may be gender-related. Men drinking at least 6 cups of coffee per day had a 54\% lower risk of diabetes, while women at the same level of coffee consumption had a 22-29\% lower risk [31, 32]. However, different results were obtained in a study in Finland, in which a very high coffee consumption (at least 10 cups per day) was associated with diabetes incidence reduction by $55 \%$ in men and $79 \%$ in women [33]. No studies have been performed to evaluate the effect of coffee consumption on the risk of diabetes type 2 in Poland. 
Metaanalyses of research studies, which provide an objective summary of the available knowledge, have also provided optimistic conclusions in this regard for years. The first of these, published in 2005, showed that people usually consuming 4-6 cups of coffee per day had a $28 \%$ lower incidence of diabetes compared to non-drinkers and those consuming less than 2 cups per day, and those consuming more than 6 cups of coffee per day had a $35 \%$ lower incidence of diabetes [34]. A subsequent 2009 metaanalysis showed a linear relationship between the amount of coffee consumed and diabetes incidence. The consumption of 3-4 cups of coffee per day was associated with a $25 \%$ reduction in diabetes incidence, and each additional cup of coffee reduced this risk by further 7\% [35]. A metaanalysis published in 2014 showed that consuming 3 cups of coffee per day was associated with a $21 \%$ reduction in diabetes incidence, and consuming 6 cups of coffee per day was associated with a $33 \%$ reduction in diabetes incidence [36]. Very similar conclusions were arrived in the most recent 2018 metaanalysis which showed that consuming 3 cups of coffee per day was associated with a $21 \%$ reduction in diabetes incidence, and consuming 5 cups of coffee per day was associated with a $29 \%$ reduction in diabetes incidence [37].

Of note, most studies available in the literature are observational epidemiological studies and not randomized clinical trials. Such studies may not account for all risk factors for diabetes, and thus the effect attributed to coffee consumption cannot be considered proven [38]. One argument against the prophylactic effect of coffee is the number of patients with diabetes in countries with a very high coffee consumption, such as Sweden and the Netherlands. According to the 2013 data, the prevalence of diabetes in these countries was $6.4 \%$ and $7.5 \%$, respectively, which is similar to the prevalence in Poland (6.5\%), where drinking coffee is much less common [39]. A hypothesis of the effect of coffee consumption on decreasing the risk of diabetes has been questioned by the results of a multicenter Mendelian randomization study which failed to show an association between coffee consumption and diabetes incidence [38].

\section{Potential mechanisms of the effect of coffee on the prevention of diabetes}

The mechanism of the effect of coffee on the risk of diabetes has not been elucidated. Short-term effects of acute coffee ingestion in individuals who do not drink it regularly are negative and include reduced insulin sensitivity and impaired glucose tolerance. In regular coffee drinkers, likely due to development of tolerance, insulin sensitivity increases and blood glucose level is lowered [32, 40]. Caffeine itself is not considered a putative mediator of this effect, as studies showed beneficial effects also for caffeine-free coffee [36, 37]. Most experts suspect that anti-inflammatory properties of coffee polyphenols may be of key importance [41]. Coffee consumption may reduce levels of proinflammatory cytokines, considered a risk factor for diabetes [42], and chlorogenic acid may inhibit hydrolysis of glucose-6-phosphate to glucose and reduce glucose absorption in the gastrointestinal tract $[30,43]$.

When considering the health effects of coffee consumption, the variable mode of brewing coffee should not be overlooked. Of note, coffee automatic machines are gaining popularity, and the health effects of coffee brewed this way have not been evaluated yet. Although experts believe that the ideal coffee brewing method in terms of its nutritional and health effects has not been defined, filtered coffee is most recommended [2, $44,45]$. It is also clear that addition of large amount of sugar or cream increases overall dietary content of these products, which may counteract positive health effects of coffee compounds. When adding two teaspoons of sugar to a cup of coffee, 3 cups of coffee, which are a considered a minimum amount associated with a reduction in diabetes incidence, provide $60 \%$ of recommended maximum daily intake of added sugar (which includes both sugar added by the consumers themselves, e.g. sweetened coffee, and sugar found in processed food). Furthermore, adding large amounts of milk may reduce the beneficial effect of polyphenols by their binding to milk protein, resulting in formation of insoluble and biologically inactive polyphenol complexes [46]. The contents of major compounds in a cup of coffee depends on the strength of the infusion. Stronger coffee contains more polyphenols but also more psychoactive caffeine. Another confounding factor is the size of a cup of coffee that is used a measure of coffee consumption. In the United Stated, a typical portion of coffee is about $250 \mathrm{~mL}$, while in Europe it is much smaller $(125-160 \mathrm{~mL})$. A cup of espresso coffee which has recently become popular contains only 25-40 mL [47-49].

\section{Summary}

Despite varying patterns of coffee consumption worldwide, studies from many research centers have yielded positive findings for coffee, supporting the hypothesis of its health benefits. Despite these optimistic data, which also suggest other benefits of coffee consumption in addition to diabetes prevention, including its potential anti-cancer effect, up to $75 \%$ of consumers still believe that coffee has a negative impact on health $[2,11]$. Thus, education efforts should be 
pursued regarding the safety of coffee consumption, so the patients will no longer worry about its negative health effects. If future findings substantiate current hypotheses, coffee lovers will include not only those who enjoy its taste but also those who will appreciate its positive health effects.

\section{Conflict of interest}

The author declares no conflicts of interests.

\section{REFERENCES}

1. Bellou V, Belbasis L, Tzoulaki I, et al. Risk factors for type 2 diabetes mellitus: An exposure-wide umbrella review of metaanalyses. PLoS One. 2018; 13(3): e0194127, doi: 10.1371/journal. pone.0194127, indexed in Pubmed: 29558518.

2. Poole R, Kennedy OJ, Roderick $P$, et al. Coffee consumption and health: umbrella review of meta-analyses of multiple health outcomes. BMJ. 2017; 359: j5024, doi: 10.1136/bmj.j5024, indexed in Pubmed: 29167102.

3. Piramida Zdrowego Żywienia. Instytut Żywności i Żywienia. www.izz.waw.pl.

4. Konstantinidi $M$, Koutelidakis $A E$. Functional foods and bioactive compounds: a review of its possible role on weight management and obesity's metabolic consequences. Medicines (Basel). 2019; 6(3): 94, doi: 10.3390/medicines6030094, indexed in Pubmed: 31505825.

5. Sanlier N, Atik A, Atik I. Consumption of green coffee and the risk of chronic diseases. Crit Rev Food Sci Nutr. 2019; 59(16): 2573-2585, doi: 10.1080/10408398.2018.1461061, indexed in Pubmed: 29624417

6. Kromhout D, Spaaij CJK, de Goede J, et al. The 2015 Dutch foodbased dietary guidelines. Eur J Clin Nutr. 2016; 70(8): 869-878, doi: 10.1038/ejen.2016.52, indexed in Pubmed: 27049034.

7. Wierzejska R. Kofeina w produkcji żywności - aspekty prawne i zdrowotne. Przemysł Spożywczy. 2013; 7: 30-33.

8. Pickering C, Kiely J. Are the current guidelines on caffeine use in sport optimal for everyone? Inter-individual variation in caffeine ergogenicity, and a move towards personalised sports nutrition. Sports Med. 2018; 48(1): 7-16, doi: 10.1007/s40279-017-0776-1, indexed in Pubmed: 28853006.

9. EFSA Panel on Dietetic Products, Nutrition and Allergies (NDA); Scientific Opinion on the safety of caffeine. EFSA Journal. 2015; 13(5): 4102

10. Międzynarodowa Statystyczna Klasyfikacja Chorób i Problemów Zdrowotnych - X Rewizja, Tom I, 2008. Centrum Systemów Informacyjnych Ochrony Zdrowia 2012.

11. Samoggia A, Riedel B. Consumers' perceptions of coffee health benefits and motives for coffee consumption and purchasing. Nutrients. 2019; 11(3), doi: 10.3390/nu11030653, indexed in Pubmed: 30889887

12. Lara B, Ruiz-Moreno C, Salinero JJ, et al. Time course of tolerance to the performance benefits of caffeine. PLoS One. 2019; 14(1): e0210275, doi: 10.1371/journal.pone.0210275, indexed in Pubmed: 30673725.

13. Southward K, Rutherfurd-Markwick KJ, Ali A. The effect of acute caffeine ingestion on endurance performance: a systematic review and meta-analysis. Sports Med. 2018; 48(8): 1913-1928, doi: 10.1007/s40279-018-0939-8, indexed in Pubmed: 29876876.

14. Mielgo-Ayuso J, Calleja-Gonzalez J, Del Coso J, et al. Caffeine supplementation and physical performance, muscle damage and perception of fatigue in soccer players: a systematic review. Nutrients. 2019; 11(2), doi: 10.3390/nu11020440, indexed in Pubmed: 30791576.

15. Scientific Opinion on the substantiation of health claims related to caffeine and increased fat oxidation leading to a reduction in body fat mass (ID 735, 1484), increased energy expenditure leading to a reduction in body weight (ID 1487), increased alert. EFSA Journal. 2011; 9(4): 2054, doi: 10.2903/j.efsa.2011.2054.

16. Nawrot $P$, Jordan $S$, Eastwood J, et al. Effects of caffeine on human health. Food Addit Contam. 2003; 20(1): 1-30, doi: 10.1080/0265203021000007840, indexed in Pubmed: 12519715.

17. Jarosz M, Wierzejska R, Siuba M. Maternal caffeine intake and its effect on pregnancy outcomes. Eur J Obstet Gynecol Reprod Biol. 2012; 160(2): 156-160, doi: 10.1016/j.ejogrb.2011.11.021, indexed in Pubmed: 22142815

18. Crozier TWM, Stalmach A, Lean MEJ, et al. Espresso coffees, caffeine and chlorogenic acid intake: potential health implications. Food Funct. 2012; 3(1): 30-33, doi: 10.1039/c1 fo10240k, indexed in Pubmed: 22130653.

19. Dankowska A, Kowalski D. Impact of selected brewing methods on caffeine content in coffee infusions. Towaroznawcze Problemy Jakości. 2018; 1(54): 53-65.

20. European Food Safety Outhority,EFSAhttps://www.efsa.europa. eu) efsaexplainscaffeine 150527

21. Zielinsky $P$, Busato $S$. Prenatal effects of maternal consumption of polyphenol-rich foods in late pregnancy upon fetal ductus arteriosus. Birth Defects Research (Part C). 2013; 99(4): 256-274 doi: 10.1002/bdrc.21051, indexed in Pubmed: 24339037.

22. Jeon JS, Kim HT, Jeong IH, et al. Contents of chlorogenic acids and caffeine in various coffee-related products. J Adv Res. 2019; 17: 85-94, doi: 10.1016/j.jare.2019.01.002, indexed in Pubmed: 31193351.

23. Guasch-Ferré M, Merino J, Sun Qi, et al. Dietary polyphenols, mediterranean diet, prediabetes, and type 2 diabetes: a narrative review of the evidence. Oxid Med Cell Longev. 2017: 6723931, doi: 10.1155/2017/6723931, indexed in Pubmed: 28883903.

24. Tajik N, Tajik M, Mack I, et al. The potential effects of chlorogenic acid, the main phenolic components in coffee, on health: a comprehensive review of the literature. Eur J Nutr. 2017; 56(7): 2215-2244, doi: 10.1007/s00394-017-1379-1, indexed in Pubmed: 28391515.

25. Ludwig IA, Clifford MN, Lean MEJ, et al. Coffee: biochemistry and potential impact on health. Food Funct. 2014; 5(8): 1695-1717. doi: 10.1039/c4fo00042k, indexed in Pubmed: 24671262.

26. Kunachowicz H, Nadolna I, Przygoda B, et al. Tabele wartości odżywczej żywności. PZWL, Warszawa, 2017.

27. van Dam RM, Feskens EJM. Coffee consumption and risk of type 2 diabetes mellitus. Lancet. 2002; 360(9344): 1477-1478, doi: 10.1016/S0140-6736(02)11436-X, indexed in Pubmed: 12433517.

28. van Dieren S, Uiterwaal CS, van der Schouw YT, et al. Coffee and tea consumption and risk of type 2 diabetes. Diabetologia. 2009; 52(12): 2561-2569, doi: 10.1007/s00125-009-1516-3, indexed in Pubmed: 19727658.

29. Iso H, Date C, Wakai K, et al. JACC Study Group. The relationship between green tea and total caffeine intake and risk for selfreported type 2 diabetes among Japanese adults. Ann Intern Med. 2006; 144(8): 554-562, doi: 10.7326/0003-4819-144-8200604180-00005, indexed in Pubmed: 16618952.

30. Sartorelli DS, Fagherazzi G, Balkau B, et al. Differential effects of coffee on the risk of type 2 diabetes according to meal consumption in a French cohort of women: the E3N/EPIC cohort study. Am J Clin Nutr. 2010; 91(4): 1002-1012, doi: 10.3945/ajcn.2009.28741, indexed in Pubmed: 20147471.

31. Pereira MA, Parker ED, Folsom AR. Coffee consumption and risk of type 2 diabetes mellitus: an 11 -year prospective study of 28 812 postmenopausal women. Arch Intern Med. 2006; 166(12): 1311-1316, doi: 10.1001/archinte.166.12.1311, indexed in Pubmed: 16801515.

32. Salazar-Martinez E, Willett WC, Ascherio A, et al. Coffee consumption and risk for type 2 diabetes mellitus. Ann Intern Med. 2004; 140(1): 1-8, doi: 10.7326/0003-4819-140-1-200401060-00005, indexed in Pubmed: 14706966.

33. Tuomilehto J, Hu G, Bidel S, et al. Coffee consumption and risk of type 2 diabetes mellitus among middle-aged Finnish men 
and women. JAMA. 2004; 291(10): 1213-1219, doi: 10.1001/ /jama.291.10.1213, indexed in Pubmed: 15010442.

34. van Dam RM, Hu FB. Coffee consumption and risk of type 2 diabetes: a systematic review. JAMA. 2005; 294(1): 97-104, doi: 10.1001/jama.294.1.97, indexed in Pubmed: 15998896.

35. Huxley R, Lee CM, Barzi F, et al. Coffee, decaffeinated coffee, and tea consumption in relation to incident type 2 diabetes mellitus: a systematic review with meta-analysis. Arch Intern Med. 2009; 169(22): 2053-2063, doi: 10.1001/archinternmed.2009.439, indexed in Pubmed: 20008687.

36. Ding M, Bhupathiraju SN, Chen Mu, et al. Caffeinated and decaffeinated coffee consumption and risk of type 2 diabetes: a systematic review and a dose-response meta-analysis. Diabetes Care. 2014; 37(2): 569-586, doi: 10.2337/dc13-1203, indexed in Pubmed: 24459154

37. Carlström M, Larsson SC. Coffee consumption and reduced risk of developing type 2 diabetes: a systematic review with metaanalysis. Nutr Rev. 2018; 76(6): 395-417, doi: 10.1093/nutrit/ nuy014, indexed in Pubmed: 29590460.

38. Kwok MKi, Leung GM, Schooling CM. Habitual coffee consumption and risk of type 2 diabetes, ischemic heart disease, depression and Alzheimer's disease: a Mendelian randomization study. Sci Rep. 2016; 6: 36500, doi: 10.1038/srep36500, indexed in Pubmed: 27845333

39. Guariguata L, Whiting DR, Hambleton I, et al. Global estimates of diabetes prevalence for 2013 and projections for 2035. Diabetes Res Clin Pract. 2014; 103(2): 137-149, doi: 10.1016/j. diabres.2013.11.002, indexed in Pubmed: 24630390.

40. Acheson KJ. Caffeine and insulin sensitivity. Metab Syndr Relat Disord. 2005; 3(1): 19-25, doi: 10.1089/met.2005.3.19, indexed in Pubmed: 18370706.

41. Santos RM, Lima DR. Coffee consumption, obesity and type 2 diabetes: a mini-review. Eur J Nutr. 2016; 55(4): 1345-1358, doi: 10.1007/s00394-016-1206-0, indexed in Pubmed: 27026242.
42. Kempf K, Herder C, Erlund I, et al. Effects of coffee consumption on subclinical inflammation and other risk factors for type 2 diabetes: a clinical trial. Am J Clin Nutr. 2010; 91(4): 950-957, doi: 10.3945/ajcn.2009.28548, indexed in Pubmed: 20181814.

43. Higdon JV, Frei B. Coffee and health: a review of recent human research. Crit Rev Food Sci Nutr. 2006; 46(2): 101-123, doi: 10.1080/10408390500400009, indexed in Pubmed: 16507475.

44. Shi L, Brunius C, Johansson I, et al. Plasma metabolite biomarkers of boiled and filtered coffee intake and their association with type 2 diabetes risk. J Intern Med. 2020; 287(4): 405-421, doi: 10.1111/joim.13009, indexed in Pubmed: 31814205.

45. Cai L, Ma D, Zhang Y, et al. The effect of coffee consumption on serum lipids: a meta-analysis of randomized controlled trials. Eur J Clin Nutr. 2012; 66(8): 872-877, doi: 10.1038/ejcn.2012.68, indexed in Pubmed: 22713771.

46. Niseteo T, Komes D, Belščak-Cvitanović A, et al. Bioactive composition and antioxidant potential of different commonly consumed coffee brews affected by their preparation technique and milk addition. Food Chem. 2012; 134(4): 1870-1877, doi: 10.1016/j.foodchem.2012.03.095, indexed in Pubmed: 23442632.

47. Derossi A, Ricci I, Caporizzi R, et al. How grinding level and brewing method (Espresso, American, Turkish) could affect the antioxidant activity and bioactive compounds in a coffee cup. J Sci Food Agric. 2018; 98(8): 3198-3207, doi: 10.1002/jsfa.8826, indexed in Pubmed: 29230816.

48. Sartini M, Bragazzi NL, Spagnolo AM, et al. Coffee Consumption and Risk of Colorectal Cancer: A Systematic Review and Meta-Analysis of Prospective Studies. Nutrients. 2019; 11(3), doi: 10.3390/nu11030694, indexed in Pubmed: 30909640.

49. Severini C, Derossi A, Ricci I, et al. Roasting conditions, grinding level and brewing method highly affect the healthy benefits of a coffee cup. Int J Clin Nutr Diet. 2018; 4(1): 127, doi: $10.15344 / 2456-8171 / 2018 / 127$ 